\title{
Remifentanil Reduces the Release of Biochemical Markers of Myocardial Damage After Coronary Artery Bypass Surgery. A Randomized Trial
}

\author{
AQ: 1 Gordon T.C. Wong, MB, BS, FANZCA, * Zhiyong Huang, MD, † Shangyi Ji, $\neq$ and Michael G. Irwin, MD, FRCA*
}

Objective: Opioids, including remifentanil, have been demonstrated to confer cardiac protection against ischemia reperfusion injury in animals. This study evaluates whether remifentanil preconditioning is protective in first time elective on pump coronary artery bypass surgery patients receiving a standardized fentanyl $(25 \mu \mathrm{g} / \mathrm{kg}$ in total) and propofol anesthetic.

Design: A prospective, double blind, randomized, controlled study.

Setting: University hospital; single institutional.

Participants: Forty patients scheduled for first time elective, on pump coronary artery bypass surgery for at least 3 diseased vessels.

Interventions: Patients randomized to the remifentanil group $(\mathrm{n}=20)$ received a $1 \mu \mathrm{g} / \mathrm{kg}$ bolus followed by 0.5 $\mu \mathrm{g} / \mathrm{kg} / \mathrm{min}$ infusion for $\mathbf{3 0}$ minutes after induction but before sternotomy, whilst the control group $(n=20)$ received normal saline. Serial samples for measurement of creatine kinase (CKMB), cardiac troponin I (cTnl), ischemia modified

A NUMBER OF TECHNIQUES and pharmacologic agents have been evaluated for their ability to trigger cardiac preconditioning in the perioperative setting. The most promising to date have been ischemia ${ }^{1}$ and volatile anesthetic agents. ${ }^{2}$ Opioids have been demonstrated to provide cardiac protection against ischemia reperfusion injury in a number of animal models $^{3}$ with the delta opioid receptor (OR) the predominate subtype implicated in mediation. ${ }^{4}$ However, very few studies have examined the clinical potential for opioid cardioprotection. Myocytes have been shown to be sites of endogenous opioid synthesis, storage and release ${ }^{5}$ and opioid levels are elevated during times of stress such as ischemia. ${ }^{6}$ Interestingly, opioids also have an important role in mammalian hibernation. This is a protective strategy to prolong survival of the brain and peripheral organs since this energy-conserving state is associated with depletion of energy stores, intracellular acidosis and hypoxia, similar to the conditions of ischemia. During hibernation, circulating levels of opioid peptides are increased dramatically, and administration of opioid antagonists can effectively reverse hibernation. Experimentally, opioids have been shown to open the potassium ATP channels of mitochondria ${ }^{7}$ and reduce the opening of the mitochondrial permeability transition pore, ${ }^{8}$ a putative end effector of cardioprotection. ${ }^{9}$

At present, neither the plasma concentration of opioids nor the duration of exposure required to induce clinical cardiac protection have been defined. In addition, different opioid receptor subtype activation may confer different degrees of ischemic tolerance. ${ }^{10}$ Remifentanil, an ultra-short acting opioid, has been shown to trigger both immediate and delayed cardiac preconditioning in the rat heart. ${ }^{11,12}$ Although relatively selective for the $\mu$ opioid receptor, its in vivo cardiac protection can be blocked by antagonists of all three opioid receptor subtypes. ${ }^{11}$ This study aimed to investigate whether the addition of remifentanil to an otherwise standardized anesthetic technique would reduce myocardial damage from cardiopulmonary bypass. albumin (IMA) and heart type fatty acid binding protein (hFABP) were taken at baseline, pre bypass, $\mathrm{T}=10$ minutes, $2,6,12$, and 24 hours after cross clamp release, to assess the degree of myocardial damage.

Measurements and Main Results: Patients in the remifentanil group had lower levels of CKMB from $\mathrm{T}=\mathbf{2}$ hours to 24 hours, $c T n l$ from $T=10$ minutes to $T=12$ hours, IMA from $T=10 \mathrm{~min}$ to $\mathrm{T}=\mathbf{2}$ hours and $\mathrm{h}-\mathrm{FABP}$ from $\mathrm{T}=10$ minutes to $T=12$ hours $(p<0.05)$. The time to tracheal extubation was shorter in patients in the remifentanil group. The overall length of ICU and hospital stays was not different.

Conclusions: The addition of remifentanil to the anesthesia regimen reduced the degree of myocardial damage. This incremental benefit may be attributable to either to remifentanil itself or to an overall increased opioid dose, the latter may be necessary to trigger cardiac protection.

(C) 2009 Elsevier Inc. All rights reserved.

KEY WORDS: myocardial protection, opioid, remifentanil, cardiac surgery

\section{METHODS}

\section{Patient Selection}

This study protocol was approved by the Institutional Ethical Committee at the Sun Yat-Sen Cardiovascular Hospital, Shenzhen, China, and informed written consent was obtained from all study subjects. Patients scheduled for first time elective, on pump coronary artery bypass surgery for at least 3 diseased vessels were recruited. Exclusion criteria included patients with a Tu score of $>9$, concomitant valve surgery, an ejection fraction of less than $30 \%$, recent myocardial infarction ( $<4$ weeks), uncontrolled hypertension, congestive cardiac failure, atrioventricular or left bundle branch block, any hepatic, renal, or pulmonary disease, any allergy to trial medications, body weight $\geq 100 \mathrm{~kg}$ or chronic opioid consumption. The Tu score is a 6-variable risk index that derives a score based on age, sex, left ventricular function, type of surgery, urgency of surgery, and repeat operation..$^{13}$ It has been validated to predict mortality and length of ICU stay following cardiac surgery. ${ }^{14,15}$ Patients' medications were continued up to the morning of surgery except for angiotensin converting enzyme inhibitors. Antiplatelet therapy (including aspirin or nonsteroidal anti-inflammatory drugs) was stopped at least 1 week prior to surgery. Patients were allocated to either the remifentanil (group R) or control group (group C) by block randomization.

\section{Anesthesia and Surgery}

All operations on study subjects were performed by the same surgeon, anesthesiologist, and perfusionist. The drug infusion was pre-

From the *Department of Anaesthesiology, University of Hong Kong, Hong Kong; and $†$ Departments of Anesthesiology and $¥$ Cardiovascular Surgery, Sun Yat-Sen Cardiovascular Hospital, Shenzhen, China.

Address reprint requests to Michael G. Irwin, MD, FRCA, Department of Anesthesiology, University of Hong Kong, Room 424, K Block, Queen Mary Hospital, Pokfulam Road, Hong Kong. E-mail: mgirwin@ $h k u . h k$

(c) 2009 Elsevier Inc. All rights reserved.

1053-0770/09/xx0x-0001\$36.00/0

doi:10.1053/j.jvca.2009.09.012 
pared by another anesthesiologist not involved with the case. The patients' anesthesiologist and intensive care unit (ICU) physicians were blinded to group allocation in this investigation. All clinical data were recorded by a clinical research assistant not involved with the clinical care of the patient.

\section{Anesthesia}

All patients received premedication with intramuscular morphine $(0.1 \mathrm{mg} / \mathrm{kg})$ and scopolamine $(5 \mu \mathrm{g} / \mathrm{kg}) 30$ minutes before the operation. After admission to the operation theatre, oxygen was administered via a face mask at $5 \mathrm{~L} / \mathrm{min}$ whilst intravenous and arterial line access was established under local anesthesia. They were monitored with 5-lead ECG, pulse oximetry, capnography, invasive arterial pressure, and pulmonary artery pressure during the operation. Anesthesia was induced with a titrated dose of etomidate until loss of eyelash reflex, followed by a bolus of fentanyl $(5 \mu \mathrm{g} / \mathrm{kg})$. Pancuronium $(0.15 \mathrm{mg} / \mathrm{kg})$ was used for muscle relaxation and tracheal intubation was performed 2 minutes later. Anesthesia was maintained in both groups with an

AQ: 3 infusion of propofol (Diprivan; Astra Zeneca, Italy), which was commenced at a rate of $60 \mathrm{mcg} / \mathrm{kg} / \mathrm{min}$ and titrated according to clinical response. Patients in group R received a remifentanil bolus of $1 \mu \mathrm{g} / \mathrm{kg}$ followed by an infusion at a rate of $0.5 \mu \mathrm{g} / \mathrm{kg} / \mathrm{min}$ for 30 minutes. This was predicted to produce a blood concentration of around $12 \mathrm{ng} / \mathrm{mL} .^{16}$ Five minutes before the end of the infusion, fentanyl was given in increments to a total dose of $20 \mu \mathrm{g} / \mathrm{kg}$, prior to sternotomy. Patients in the control group received $0.9 \%$ saline instead of remifentanil given at the same infusion rate. The mean arterial pressure was maintained within $20 \%$ of the pre operative value and above $60 \mathrm{mmHg}$. This was achieved either with boluses of $0.5 \mu \mathrm{g} / \mathrm{kg}$ phenylephrine to increase arterial pressure or increasing the dose of propofol or the use of glyceryl trinitrate to reduce arterial pressure. At the conclusion of the operation, propofol sedation was continued in the intensive care unit.

\section{Hemodynamic Monitoring}

The right internal jugular vein and left radial artery were used for hemodynamic monitoring. Heart rate (HR), mean arterial pressure (MAP), pulmonary capillary wedge pressure (PCWP), central venous pressure (CVP), cardiac index (CI), systemic vascular resistance index (SVRI), and left ventricular stroke work index (LVSWI) were monitored using a radial arterial catheter and Swan-Ganz catheter (Space AQ: 4 Labs). Data were collected at baseline, preaortic cross clamp (ACC), and 10 minutes, 2, 6, 12, and 24 hours postaortic cross clamp release (ACCR), which was designated as $\mathrm{T}=0$. In this study intraoperative hypotension was defined as $30 \%$ less than that at baseline for a patient with hypertension, or a MAP below $60 \mathrm{mmHg}$.

\section{Cardiopulmonary Bypass}

The Stockert-II heart-lung machine with roller pump and Affinity membrane oxygenator (Medtronic) were used. The CPB circuit, the oxygenator, and the arterial filter (Xi Jing, Xian, China) were primed with $1500 \mathrm{~mL}$ of Ringer's lactate containing $0.5 \mathrm{~g} / \mathrm{kg}$ of mannitol and $5000 \mathrm{IU}$ of heparin. In both groups heparin was administered at a dose of $3 \mathrm{mg} / \mathrm{kg}$ to achieve an activated clotting time (ACT) of 480 seconds or greater before commencement of CPB. The nonpulsatile pump flows were adjusted to maintain a cardiac index between $2.4 \mathrm{~L} / \mathrm{min} / \mathrm{m}^{2}$ and $2.6 \mathrm{~L} / \mathrm{min} / \mathrm{m}^{2}$. Anterograde intermittent administration of a cold cardioplegic solution, histidine-triptophan-ketoglutal (HTK; Custodial Dr. Koehler Chemie GMBH, Alsbach-Haenlein, Germany) was administered both through the aortic root and through the graft after completion of each distal anastomosis.

\section{Laboratory Assay}

Blood samples were collected from each patient after measuring hemodynamic indices (see above). Samples were cooled to $4^{\circ} \mathrm{C}$ and centrifuged at $3000 \mathrm{rpm}$ for 10 minutes at $4^{\circ} \mathrm{C}$. Serum was stored at $-70^{\circ} \mathrm{C}$ until assay. Serum levels of heart-type fatty acid-binding protein (h-FABP) were measured by enzyme-linked immunosorbent assay (IgCon Therapeutics Co. Ltd, Shanghai, China). Ischemia-modified albumin (IMA) levels were measured by the albumin cobalt binding test on a Cobas Mira Plus analyzer (Roche). The albumin cobalt AQ: 5 binding method has been validated in previous studies. ${ }^{13,17}$ Free cobalt can be measured with spectrophotometric methods and this indicates the IMA level. The cutoff point of IMA for myocardial ischemia was accepted as $85 \mathrm{U} / \mathrm{L}$ according to the manufacturer's recommendation. ${ }^{18,19}$ Levels of MB isoenzyme of creatine kinase (CK-MB) were calculated using the photometric method (DiaSys Diagnostic System $\mathrm{GmbH}$, Holzheim, Germany). Cardiac troponin I (cTnI) levels were measured using immunometric technology (Chuanzhi Biomedical Products Corp., Taiyuan, China). The detection range for cTnI was $0.1-50 \mathrm{ng} / \mathrm{mL}$, and a cTnI value above $0.5 \mathrm{ng} / \mathrm{mL}$ was considered as abnormal.

\section{ELECTROCARDIOGRAPHIC CHANGES}

A 12-lead electrocardiogram was recorded preoperatively and then daily postoperatively. The electrocardiographic diagnosis criteria for perioperative myocardial infarction (PMI) was 1 or more of more of the following: new Q waves of more than 0.04 seconds; a reduction in $\mathrm{R}$ waves of more than $25 \%$ in at least 2 leads; significant ST segment deviation (elevation at the $\mathrm{J}$ point in 2 or more contiguous leads with cut-off point $\geq 0.2$ $\mathrm{mV}$ in leads $\mathrm{V} 1, \mathrm{~V} 2$, or $\mathrm{V} 3$, and $\geq 0.1 \mathrm{mV}$ in other leads) or $\mathrm{T}$ wave abnormalities in 2 or more contiguous leads and new left bundle branch block. Intra-operative arrhythmia was considered as 1 of the following: atrioventricular block, sustained premature ventricular contractions, ventricular tachycardia, atrial or ventricular fibrillation.

\section{Criteria for Inotrope Administration}

Inotrope support was considered in the post bypass period if 1 or more of the following occurred: (1) mean arterial pressure was less than $60 \mathrm{mmHg}$ or decreased more than $20 \%$ from the baseline value; (2) cardiac output index (CI) was less than 2.2 $\mathrm{L} / \mathrm{min} / \mathrm{m}^{2}$ or (3) CVP or PCWP was more than $12 \mathrm{mmHg}$. For the latter, nitroglycerin ( 1 to $10 \mu \mathrm{g} / \mathrm{kg} / \mathrm{min}$ ) or sodium nitroprusside $(0.5$ to $10 \mu \mathrm{g} / \mathrm{kg} / \mathrm{min})$ was administered in addition to inotrope support. Dopamine was initially administered at a dose of up to $5 \mu \mathrm{g} / \mathrm{kg} / \mathrm{min}$. If there was no improvement, the dose of dopamine would then either be increased or changed to a combination of dobutamine $(5 \mu \mathrm{g} / \mathrm{kg} / \mathrm{min})$ plus epinephrine starting at $0.03 \mu \mathrm{g} / \mathrm{kg} / \mathrm{min}$. An intra-aortic balloon pump was considered if the epinephrine dose reached $0.1 \mu \mathrm{g} / \mathrm{kg} / \mathrm{min}$. The patient's inotrope requirement was classified as none, mild (dopamine $\leq 5 \mu \mathrm{g} / \mathrm{kg} / \mathrm{min}$ ) or moderate (dopamine $>5$ $\mu \mathrm{g} / \mathrm{kg} / \mathrm{min}$ or dobutamine $>5 \mu \mathrm{g} / \mathrm{kg} / \mathrm{min}$ or epinephrine $<0.1$ $\mu \mathrm{g} / \mathrm{kg} / \mathrm{min})$.

\section{Statistical Analysis}

Sample size was calculated using cardiac troponin levels as the primary outcome. A minimum detected difference of 0.5 $\mathrm{ng} / \mathrm{mL}$ at $\mathrm{T}=6$ between groups was considered significant. A sample size of at least 14 was required to achieve a power of 0.9 and a 2 -sided $\alpha$ error of 0.05 . Categorical variables are presented by their number, summarized as a percentage and compared using $\chi^{2}$ or Fisher's exact test where appropriate. 
\begin{tabular}{|l|l|l|l|l|}
\hline tapraid2/zl0-jcan/zl0-jcan/zl099908/zl02542d08z & comp1 & $\mathrm{S}=1$ & 11/30/09 & Art: 1614 \\
\hline
\end{tabular}

Comparisons of continuous variables between groups were analyzed by unpaired $t$ test. The time course of hemodynamic data was analyzed between groups by 2-way ANOVA for repeated measurements. When a significant overall effect was detected, Tukey's honest significance difference test was performed to compare single mean values. Data for the biochemical markers (CK-MB, cTnI, IMA, and h-FABP) were analyzed for normality with the Kolmogorov-Smirnov test. Nonparametric data were compared at each time point using the Mann Whitney $U$ test. Comparison of the areas under the curve for all the markers was also made using unpaired $t$ test. Differences were considered significant at a value of $p<0.05$. Statistical analyses were performed using the SPSS statistical software package, version 13.0 (SPSS Inc., Chicago, IL).

\section{RESULTS}

Forty patients were recruited and randomized into either the control $(n=20)$, or remifentanil group $(n=20)$. There were no significant differences in patient characteristics in terms of demographics, medications, preexisting medical conditions,

T1 laboratory results and cardiac function (Table 1). Surgical revascularization was successfully achieved in all patients and there were no differences in surgical and perfusion parameters between groups.

The results of the primary outcome of biochemical marker F1 release are shown in Figure 1A to 1D. As the values for the biochemical markers of myocardial ischemia and cellular damage did not have a Gaussian distribution, they were processed in a nonparametric fashion. There were elevations in all tested markers after CPB when compared with baseline. They returned to baseline values at $\mathrm{T}=6$ for IMA and $\mathrm{T}=24$ for h-FABP. The remifentanil group had lower levels of CK-MB at $\mathrm{T}=2,6,12$, and 24 hours and lower $\mathrm{cTnI}$ at $\mathrm{T}=10$ minutes, 2,6 , and 12 hours. IMA levels were lower at $\mathrm{T}=10$ minutes and 2 hours as were the h-FABP levels at these times as well as at $\mathrm{T}=12$ hours.

Although not powered for clinical outcome parameters, there were some trends noted between the 2 groups. These included significantly more patients with episodes of arrhythmia in the control group. In addition there were more patients in the control group that required defibrillation to restore sinus T2, AQ:6 rhythm after reperfusion (Table 2).

In the pre bypass period, patients in the remifentanil group had lower MAP as well as systemic vascular resistance index. In the first 2 hours $(T=2)$ following the release of the aortic cross clamp $(\mathrm{T}=0)$ the remifentanil group had significantly greater left ventricular stroke work index and cardiac index

T3, AQ:7 (Table 3). Post operatively there were fewer patients requiring inotrope support in the remifentanil group and, for those that did, infusion rates were lower. One patient in the control group developed a postoperative myocardial infarction that later required IABP support. More patients had ECG changes postoperatively in the control group. The time to tracheal extubation was shorter in patients in the remifentanil group. However, the overall length of ICU and hospital stays was not different between the 2 groups and there were no deaths in any of the T4, AQ:8 patients in the study (Table 4).
Table 1. Preoperative Patient Data

\begin{tabular}{|c|c|c|}
\hline Variables & Group C $(n=20)$ & Group $R(n=20)$ \\
\hline \multicolumn{3}{|l|}{ Demographics } \\
\hline Age (y) & $65.6 \pm 3$ & $64.50 \pm 2$ \\
\hline $\operatorname{Sex}(M / F)$ & $15 / 5$ & $14 / 6$ \\
\hline Weight (kg) & $69.50 \pm 10.2$ & $68.10 \pm 7.6$ \\
\hline $\operatorname{BSA}\left(\mathrm{m}^{2}\right)$ & $1.69 \pm 0.41$ & $1.72 \pm 0.34$ \\
\hline \multicolumn{3}{|l|}{ Preoperative medications } \\
\hline$\beta$ blockers & 14 & 13 \\
\hline Calcium blockers & 7 & 8 \\
\hline ACE inhibitors & 8 & 9 \\
\hline Nitrates & 16 & 17 \\
\hline Diuretics & 5 & 5 \\
\hline Sulfonylurea & 4 & 3 \\
\hline Insulin & 6 & 5 \\
\hline Aspirin & 14 & 15 \\
\hline \multicolumn{3}{|l|}{ Other diseases } \\
\hline Diabetes & 7 & 6 \\
\hline Hypertension & 7 & 8 \\
\hline COPD & 3 & 2 \\
\hline Peripheral Vascular Disease & 2 & 1 \\
\hline Tu Score & $3.14 \pm 0.4$ & $3.05 \pm 0.3$ \\
\hline \multicolumn{3}{|l|}{ Laboratory test } \\
\hline Hemoglobin (g/L) & $125.5 \pm 23.2$ & $123.7 \pm 11.6$ \\
\hline Platelet count $\left(10^{9} / \mathrm{L}\right)$ & $215.5 \pm 36.7$ & $224.2 \pm 48.5$ \\
\hline ALT & $20.1 \pm 7.5$ & $18.7 \pm 3.1$ \\
\hline AST & $31.2 \pm 10.3$ & $30.6 \pm 12.3$ \\
\hline Albumin (g/L) & $42.2 \pm 7.5$ & $41.1 \pm 3.1$ \\
\hline Urea $(\mu \mathrm{mol} / \mathrm{L})$ & $233.2 \pm 57.3$ & $219.6 \pm 48.2$ \\
\hline Creatinine $(\mu \mathrm{mol} / \mathrm{L})$ & $120.3 \pm 36.5$ & $104.3 \pm 20.1$ \\
\hline \multicolumn{3}{|l|}{ Cardiac status } \\
\hline Previous MI (>4 weeks) & 8 & 9 \\
\hline LVEF $30 \%-49 \%$, & 4 & 5 \\
\hline LVEF $>49 \%$ & 16 & 15 \\
\hline LMCA stenosis > $>50 \%$ & 14 & 15 \\
\hline
\end{tabular}

NOTE. Data are presented as mean \pm SD or number $(n)$.

Abbreviations: BSA, body surface area; $A C E$, angiotensin-converting enzyme; COPD, chronic obstructive pulmonary disease; ALT, alanine aminotransferase; AST, aspartate aminotransferase; MI, myocardial infarction; LVEF, left ventricular ejection fraction; LMCA, left main coronary artery; NS, not significant.

\section{DISCUSSION}

Results from this study suggest that a short period of high dose remifentanil before cardiopulmonary bypass confers a preconditioning effect over and above that provided by fentanyl. From laboratory data, there was an increase in infarct sparing effect with increasing dose of remifentanil. ${ }^{11}$ Clinically, blood concentrations of $4-8 \mathrm{ng} / \mathrm{mL}$ produce little further reduction in the minimal alveolar concentration of isoflurane (a measure of opioid potency $)^{20}$ and a blood concentration of 7.5 $\mathrm{ng} / \mathrm{mL}$ depresses the epinephrine response to pneumoperitoneum and surgery. ${ }^{21}$ An infusion regime was, therefore, chosen that would produce blood concentrations of around $12 \mathrm{ng} / \mathrm{mL}$ which is a dose sufficiently high to reduce the stress response of surgery. The 30-minute infusion period was chosen as laboratory data showed that three 5 minute infusions of remifentanil interspersed with 5-minute infusion free periods (a total of 30 minutes) was sufficient to demonstrate a preconditioning response in our animal studies. A decision was made not to 

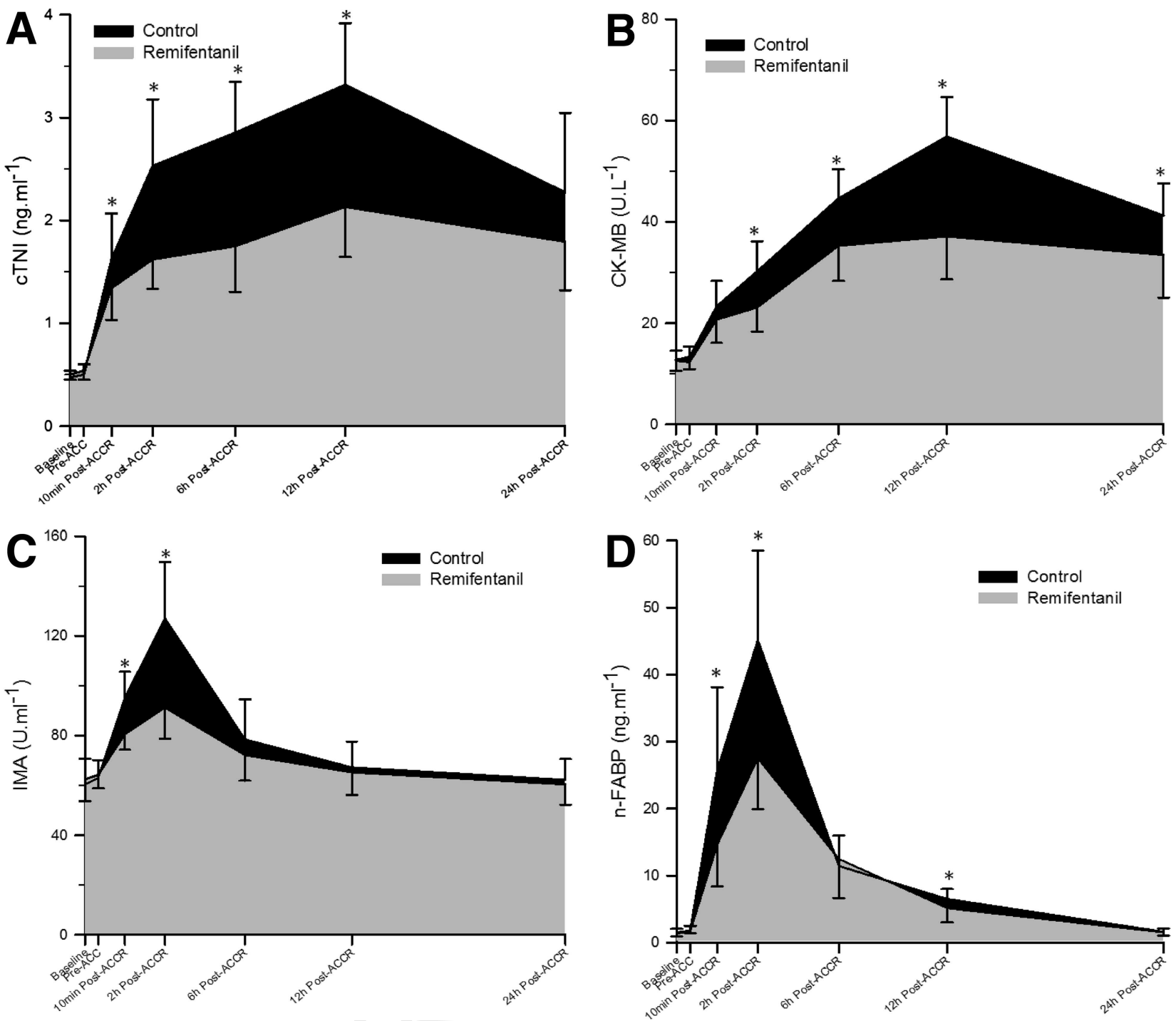

Fig 1. Blood levels of biochemical markers over time. Values are plotted as median (error bars = interquartile range). Pre-ACC, period before aortic cross clamp was applied; ACCR, aortic cross clamp release. $* p<0.05$.

pulse the delivery of remifentanil to avoid hemodynamic instability that such a regime may introduce. Once triggered, a preconditioning response should have a protective window of several hours and the concentrations of remifentanil should have dissipated by the time of cross clamping.

A number of agents including those used in the perioperative period have been demonstrated to protect the myocardium. This study attempted to minimize the use of such agents as they could have acted as confounders, and other drug use was the same in both groups. Propofol was used rather than a volatile anesthetic as certain volatile agents have been shown to confer acute preconditioning. ${ }^{22,23}$ Propofol too has been shown in 1 study to protect the heart during bypass surgery, probably via its antioxidant properties. ${ }^{24}$ During the remifentanil infusion period, the control group may have temporarily received a higher dose of propofol than the remifentanil group, which may potentially reduce the differences between groups. However, the dose used in the control would have been less than that shown to be cardioprotective. As it would be unethical to exclude the use of opioids in cardiac surgical patients, the same dose of fentanyl was used in both groups to equalize the effect this opioid may have had on outcome. Any difference in potency between fentanyl and remifentanil should, therefore, not affect the outcome. In addition to the conventional markers of cardiac damage after cardiopulmonary bypass (CKMB and cardiac troponin I $)^{25}$, we also employed 2 innovative markers that are not routinely used. Ischemia modified albumin (IMA) is a metabolic variant of albumin that may represent an innate, endogenous response to ischemia. ${ }^{26}$ In addition to myocardial ischemia, ${ }^{18,27}$ its level is increased in acute stroke ${ }^{28}$, skeletal muscle ischemia ${ }^{29}$ and pulmonary embolism. ${ }^{30}$ It has reduced binding capacity to transition metals such as cobalt, copper or nickel and this property is exploited during laboratory measurements. It has rapid kinetics, rising within 30 minutes and 
Table 2. Intraoperative Data

\begin{tabular}{|c|c|c|c|}
\hline Variable & Group C $(n=20)$ & Group R $(n=20)$ & $p$ Value \\
\hline Pre bypass fluids $(\mathrm{mL})$ & $854 \pm 138$ & $869 \pm 142$ & 0.73 \\
\hline Patients requiring phenylephrine pre bypass $(n)$ & 10 & 17 & 0.02 \\
\hline Post bypass fluids (mL) & $1327 \pm 372$ & $1294 \pm 331$ & 0.75 \\
\hline HTK $(m L)$ & $1841 \pm 248$ & $1715 \pm 269$ & 0.14 \\
\hline Aortic cross-clamping time (min) & $78 \pm 12$ & $75 \pm 8$ & 0.38 \\
\hline Aortic side-clamping (min) & $41 \pm 13$ & $39 \pm 5$ & 0.59 \\
\hline CPB time ( $\mathrm{min})$ & $152 \pm 28$ & $147 \pm 34$ & 0.59 \\
\hline Operation time ( $\min )$ & $248 \pm 35$ & $236 \pm 33$ & 0.27 \\
\hline Number of grafts & $3.2 \pm 0.7$ & $3.1 \pm 0.5$ & 0.61 \\
\hline \multicolumn{4}{|l|}{ Number of patients requiring cardioversion to } \\
\hline Dopamine time (min) & $56 \pm 20$ & $48 \pm 17$ & 0.17 \\
\hline Dopamine average dose $(\mu \mathrm{g} / \mathrm{kg} / \mathrm{min})$ & $3.51 \pm 0.57$ & $2.78 \pm 1.61$ & 0.06 \\
\hline Phenylephrine (mg) & $0.21 \pm 0.06$ & $0.23 \pm 0.09$ & 0.41 \\
\hline Propofol (mg) & $1120 \pm 203$ & $1204 \pm 251$ & 0.25 \\
\hline Fentanyl ( $\mu \mathrm{g})$ & $1.75 \pm 0.2$ & $1.7 \pm 0.2$ & 0.43 \\
\hline \multicolumn{4}{|l|}{ Post bypass adverse events } \\
\hline Bradycardia (n) & 4 & 5 & 1.0 \\
\hline Hypotension (n) & 5 & 6 & 1.0 \\
\hline Arrhythmias (n) & 8 & 2 & 0.03 \\
\hline
\end{tabular}

NOTE. Data are presented as mean \pm SD or number $(n)$.

Abbreviations: Arrhythmia, atrioventricular block, sustained premature ventricular contractions, ventricular tachycardia, atrial or ventricular fibrillation occurring after separation from cardiopulmonary bypass but before arrival in ICU. HTK, histidine-triptophan-ketoglutala, a type of cardioplegia solution; $\mathrm{CPB}$, cardiopulmonary bypass.

returning to baseline within 12 hours after percutaneous angioplasty procedures. ${ }^{18}$ Heart type fatty acid binding protein (hFABP) is a small water soluble intracellular protein that resides in the cytoplasm. ${ }^{31}$ Due to its small size, it is rapidly released into the bloodstream following sarcolemmal damage. ${ }^{32}$ It has been shown to peak as early as 60 minutes after reperfusion following cardiopulmonary bypass, much earlier than CKMB and troponin. ${ }^{33,34}$

As opioids were used in both groups, interpretation of these results must be tempered with caution as it may be accounted for by a number of possible explanations. First, there could be a difference in cardioprotective properties between remifentanil and fentanyl due to a different affinity for opioid receptor subtypes, as all other anesthetic and surgical factors were similar in both groups except for the use of remifentanil. We feel that this is an unlikely explanation. Remifentanil is chemically related to fentanyl and both are predominantly $\mu$ opioid receptor agonists. ${ }^{35}$ Remifentanil also has some action on delta and, to a lesser extent, kappa opioid receptors. ${ }^{36}$ The cardiac preconditioning effect of remifentanil in vivo can be blocked

Table 3. Patients' Perioperative Hemodynamic Data

\begin{tabular}{|c|c|c|c|c|c|c|c|c|}
\hline \multirow[b]{2}{*}{ Variable } & \multirow[b]{2}{*}{ Group } & \multirow[b]{2}{*}{ Baseline } & \multirow[b]{2}{*}{ Pre-ACC } & \multicolumn{5}{|c|}{ Post-ACCR } \\
\hline & & & & $10 \mathrm{~min}$ & 2 hours & 6 hours & 12 hours & 24 hours \\
\hline \multirow[t]{2}{*}{ HR (beats/min) } & $\mathrm{C}$ & $72 \pm 14$ & $75 \pm 14$ & $68.2 \pm 11$ & $82 \pm 14$ & $85 \pm 20$ & $79 \pm 10$ & $83 \pm 8$ \\
\hline & $\mathrm{R}$ & $74 \pm 20$ & $76 \pm 18$ & $70.6 \pm 20$ & $88 \pm 25$ & $83 \pm 23$ & $80 \pm 16$ & 88. \pm 11 \\
\hline \multirow[t]{2}{*}{$\mathrm{MAP}(\mathrm{mmHg})$} & $\mathrm{C}$ & $94 \pm 14$ & $88 \pm 20$ & $64 \pm 15$ & $83 \pm 13$ & $88 \pm 10$ & $85 \pm 20.3$ & $88 \pm 17$ \\
\hline & $\mathrm{R}$ & $90 \pm 18$ & $70 \pm 13^{\#}$ & $71 \pm 22$ & $86 \pm 17$ & $88 \pm 12$ & $83 \pm 18$ & $90 \pm 18$ \\
\hline \multirow[t]{2}{*}{ CVP (mmHg) } & $\mathrm{C}$ & $8 \pm 1$ & $8 \pm 2$ & $9 \pm 2$ & $9 \pm 2$ & $9 \pm 1$ & $10 \pm 1$ & $11 \pm 3$ \\
\hline & $\mathrm{R}$ & $8 \pm 2$ & $8 \pm 2$ & $9 \pm 2$ & $9 \pm 2$ & 9. \pm 1 & $10 \pm 1$ & $11 \pm 4$ \\
\hline \multirow[t]{2}{*}{ PCWP (mmHg) } & $\mathrm{C}$ & $8 \pm 1$ & $8 \pm 1$ & $7 \pm 1$ & $8 \pm 1$ & $9 \pm 1$ & $10 \pm 1$ & $12 \pm 4$ \\
\hline & $\mathrm{R}$ & $8 \pm 1$ & $7 \pm 1$ & $7 \pm 1$ & $8 \pm 1$ & $9 \pm 1$ & $10 \pm 1$ & $12 \pm 3$ \\
\hline \multirow[t]{2}{*}{$\mathrm{Cl}\left(\mathrm{L} / \mathrm{min} / \mathrm{m}^{2}\right)$} & $\mathrm{C}$ & $1.9 \pm 0.1$ & $1.9 \pm 0.2$ & $2.0 \pm 0.3$ & $2.2 \pm 0.3$ & $2.5 \pm 0.6$ & $2.6 \pm 0.3$ & $2.4 \pm 0.3$ \\
\hline & $\mathrm{R}$ & $1.8 \pm 0.2$ & $2.7 \pm 0.2^{\#}$ & $2.3 \pm 0.3$ & $2.5 \pm 0.13^{\#}$ & $2.5 \pm 0.3$ & $2.5 \pm 0.4$ & $2.5 \pm 0.2$ \\
\hline \multirow[t]{2}{*}{ SVRI (dynes $\left.\times \mathrm{s} \times \mathrm{cm}^{-5} / \mathrm{m}^{2}\right)$} & $\mathrm{C}$ & $2984 \pm 526$ & $2606 \pm 437^{\#}$ & $2448 \pm 371$ & $2506 \pm 417$ & $2671 \pm 315$ & $2318 \pm 329$ & $2571 \pm 344$ \\
\hline & $\mathrm{R}$ & $2738 \pm 369$ & $1872 \pm 238$ & $2287 \pm 318$ & $2482 \pm 339$ & $2581 \pm 403$ & $2481 \pm 278$ & $2392 \pm 276$ \\
\hline \multirow[t]{2}{*}{ LVSWI $\left(\mathrm{g} \times \mathrm{m} / \mathrm{m}^{2}\right)$} & $\mathrm{C}$ & $25.5 \pm 9$ & $30.5 \pm 8.4$ & $34.1 \pm 12.3$ & $37.6 \pm 9.1$ & $38.5 \pm 7.4$ & $37.3 \pm 9.3$ & $38.5 \pm 12.7$ \\
\hline & $\mathrm{R}$ & $28.3 \pm 22$ & $31.3 \pm 9.2$ & $43.3 \pm 8 . \#$ & $48.2 \pm 10.2^{\#}$ & $43.3 \pm 11.5$ & $41.4 \pm 8.5$ & $40.3 \pm 10.4$ \\
\hline
\end{tabular}

NOTE. Data are presented as mean \pm SD.

Abbreviations: \#, difference between control and remifentanil groups ( $p<0.05)$; C, control group; $\mathrm{R}$, remifentanil group; ACC, aortic cross-clamping; ACCR, aortic cross clamp release; HR, heart rate; MAP, mean arterial pressure; CVP, central venous pressure; PCWP, pulmonary capillary wedge pressure; $\mathrm{Cl}$, cardiac index; SVRI, systemic vascular resistance index; LVSWI, left ventricle stroke work index. 
Table 4. Postoperative Data

\begin{tabular}{lccl}
\hline \multicolumn{1}{c}{ Variable } & $\begin{array}{c}\text { Group C } \\
(\mathrm{n}=20)\end{array}$ & $\begin{array}{c}\text { Group R } \\
(\mathrm{n}=20)\end{array}$ & $p$ Value \\
\hline Inotrope use & & & \\
$\quad$ None (n) & 3 & 8 & 0.07 \\
Mild (n) & 11 & 12 & 1.0 \\
$\quad$ Moderate (n) & 6 & 0 & 0.02 \\
Postoperative MI (n) & 1 & 0 & 1.0 \\
ST-segment deviations (n) & 7 & 3 & 0.14 \\
New path. Q-waves, (n) & 4 & 1 & 0.34 \\
Requirement for IABP (n) & 1 & 0 & 1.0 \\
Tracheal extubation (hours) & $15 \pm 3$ & $13 \pm 3$ & 0.04 \\
ICU stay (hours) & $38 \pm 9$ & $36 \pm 11$ & 0.39 \\
Hospital stay (days) & $13 \pm 4$ & $11 \pm 3$ & 0.1 \\
Death in hospital (n) & 0 & 0 & 1.0 \\
\hline
\end{tabular}

NOTE. Data are presented as mean \pm SD or number $(n)$. Inotrope use, mild $=$ dopamine $<5 \mu \mathrm{g} / \mathrm{kg} / \mathrm{min}$; moderate $=$ dopamine $/$ dobutamine $>5 \mu \mathrm{g} / \mathrm{kg} / \mathrm{min}$ or epinephrine $<0.1 \mu \mathrm{g} / \mathrm{kg} / \mathrm{min}$.

Abbreviations: MI, myocardial infarction; IABP, intra-aortic balloon pump; ICU, intensive care unit.

by $\delta$ and $\kappa$ as well as mu receptor antagonists. ${ }^{11,37}$ However, this observation may also be a result of functional interaction or "cross talk" between different opioid receptor subtypes, ${ }^{38,39}$ whereby activation or blockade of 1 subtype could possibly influence other subtypes. Fentanyl can also protect the heart in vitro via the delta receptor. ${ }^{40}$ However, there is little data directly comparing the opioid receptor subtype affinity in cardiac tissue between fentanyl and remifentanil.

It is more likely that the results are simply a function of the difference in the total dose of opioid given. The potency of remifentanil is similar to fentanyl. ${ }^{41} \mathrm{~A}$ higher plasma concentration of total opioid in the remifentanil group may have had a more powerful agonist effect on the appropriate receptors on a greater number of cells in a heart with diseased vessels. This could have clinical implications for patients undergoing on pump cardiac surgery. High doses of opioids were commonly used for cardiac anesthesia in the past ${ }^{42}$ but have now been substantially reduced, commensurate with the trend towards fast track surgery. Remifentanil, however, has unique pharmacokinetic properties that allow rapid onset of high target opioid concentrations intraoperatively with very rapid recovery on cessation of infusion avoiding the usual consequence of prolonged respiratory depression. ${ }^{41,43}$ Studies comparing the use of remifentanil versus fentanyl in this setting have concluded that remifentanil is safe and suitable for fast track surgery. ${ }^{44,45}$
Furthermore in these studies, there were indications that higher opioid doses may be beneficial. There were fewer patients suffering myocardial infarction in the remifentanil and high dose fentanyl group compared with a low dose fentanyl group in the study by Myles and colleagues. ${ }^{45}$ In 2 other studies there was also a trend towards lower CKMB levels in the remifentanil group in $1^{44}$ and statistically lower CKMB and a trend towards lower troponin $\mathrm{T}$ levels in the other. ${ }^{46}$ However, in the latter 2 studies volatile anesthetic agents were also used and that may have influenced the results.

There are several limitations to this study. This was a small study that was not statistically powered to judge certain clinical outcomes such as the incidence of death or myocardial infarction. As mentioned, it was not possible to avoid the use of opioids in the control group as this is standard practice in cardiac anesthesia and, therefore, fentanyl was used. It follows that any anticipated difference between the 2 groups would be small and hence our choice of $0.5 \mathrm{ng} / \mathrm{mL}$ as a significant difference when calculating the study power. Plasma drug concentrations were not measured and, since only a single dose was used, there is no dose response data. The results do suggest that either remifentanil or an increased overall opioid dose is beneficial but the question of whether 1 opioid is superior to another remains unanswered.

Oxidative stress as a result of reperfusion injury is a known causative factor of cardiac muscle injury and may occur after cardiac bypass. ${ }^{47}$ Myocardial reperfusion injury is also seen after the use of primary percutaneous coronary intervention following myocardial infarction where it has been suggested that this may account for significant morbidity and up to $50 \%$ of the final size of the infarct. ${ }^{48,49}$ Pharmacologic attempts to target known mediators of this process have generally been ineffective, although, recently, cyclosporine administered immediately before primary PCI significantly reduced the release of CK, cTnI and infarct size. ${ }^{50}$ Perhaps remifentanil may be worthy of further study in this setting.

In conclusion, the results from this study demonstrate that the addition of high doses of remifentanil prior to sternotomy, reduced cardiac injury during on pump coronary artery bypass surgery as manifest by a reduction in the release of a range of biochemical markers. High dose opioids, particularly in conjunction with the pharmacokinetics of remifentanil, may represent a clinically simple and safe technique for cardiac preconditioning.
AQ: 9

1. Hausenloy DJ, Mwamure PK, Venugopal V, et al: Effect of remote ischaemic preconditioning on myocardial injury in patients undergoing coronary artery bypass graft surgery: A randomised controlled trial. Lancet 370:575-579, 2007

2. Bignami E, Biondi-Zoccai G, Landoni G, et al: Volatile anesthetics reduce mortality in cardiac surgery. J Cardiothorac Vasc Anesth 2009

3. Schultz JE, Gross GJ: Opioids and cardioprotection. Pharmacol Ther 89:123-137, 2001

4. Schultz JJ, Hsu AK, Gross GJ: Ischemic preconditioning and morphine-induced cardioprotection involve the delta $(\delta)$-opioid receptor in the intact rat heart. J Mol Cell Cardiol 29:2187-2195, 1997

\section{REFERENCES}

5. Barron BA: Cardiac opioids. Proc Soc Exp Biol Med 224:1-7, 2000

6. Eliasson T, Mannheimer C, Waagstein F, et al: Myocardial turnover of endogenous opioids and calcitonin-gene-related peptide in the human heart and the effects of spinal cord stimulation on pacinginduced angina pectoris. Cardiology 89:170-177, 1988

7. Cohen MV, Yang XM, Liu GS, et al: Acetylcholine, bradykinin, opioids, and phenylephrine, but not adenosine, trigger preconditioning by generating free radicals and opening mitochondrial K(ATP) channels. Circ Res 89:273-278, 2001

8. Jang Y, Xi J, Wang H, Mueller RA, et al: Postconditioning prevents reperfusion injury by activating delta-opioid receptors. Anesthesiology 108:243-250, 2008 
9. Javadov S, Karmazyn M, Javadov S, et al: Mitochondrial permeability transition pore opening as an endpoint to initiate cell death and as a putative target for cardioprotection. Cell Physiol Biochem 20:1-22, 2007

10. Romano MA, McNish R, Seymour EM, et al: Differential effects of opioid peptides on myocardial ischemic tolerance. J Surg Res 119:46-50, 2004

11. Zhang Y, Irwin MG, Wong TM: Remifentanil preconditioning protects against ischemic injury in the intact rat heart. Anesthesiology 101:918-923, 2004

12. Yu CK, Li YH, Wong GT, et al: Remifentanil preconditioning confers delayed cardioprotection in the rat.[see comment]. Br J Anaesth 99:632-638, 2007

13. Wu AH, Morris DL, Fletcher DR, et al: Analysis of the albumin cobalt binding (ACB) test as an adjunct to cardiac troponin I for the early detection of acute myocardial infarction. Cardiovasc Toxicol $1: 147-151,2001$

14. Tu JV, Jaglal SB, Naylor CD: Multicenter validation of a risk index for mortality, intensive care unit stay, and overall hospital length of stay after cardiac surgery. Circulation, 91:677-684, 1995

15. Leonard RC, van Heerden PV, Power BM, et al: Validation of Tu's cardiac surgical risk prediction index in a Western Australian population. Anaesth Intensive Care 27:182-184, 1999

16. Minto CF, Schnider TW, Shafer SL: Pharmacokinetics and pharmacodynamics of remifentanil. II. Model application. Anesthesiology 86:24-33, 1997

17. Christenson RH, Duh SH, Sanhai WR, et al: Characteristics of an albumin cobalt binding test for assessment of acute coronary syndrome patients: A multicenter study. Clin Chem 47:464-470, 2001

18. Sinha MK, Gaze DC, Tippins JR, et al: Ischemia modified albumin is a sensitive marker of myocardial ischemia after percutaneous coronary intervention. Circulation 107:2403-2405, 2003

19. Wu AH, Wu AHB: The ischemia-modified albumin biomarker for myocardial ischemia. MLO Med Lab Obs 35:36-38, 2003

20. Lang E, Kapila A, Shlugman D, et al: Reduction of isoflurane minimal alveolar concentration by remifentanil. Anesthesiology 85: 721-728, 1996

21. Myre K, Raeder J, Rostrup M, et al: Catecholamine release during laparoscopic fundoplication with high and low doses of remifentanil. Acta Anaesthesiol Scand 47:267-273, 2003

22. Landoni G, Biondi-Zoccai GG, Zangrillo A, et al: Desflurane and sevoflurane in cardiac surgery: A meta-analysis of randomized clinical trials. J Cardiothorac Vasc Anesth 21:502-511, 2007

23. Guarracino F, Landoni G, Tritapepe L, et al: Myocardial damage prevented by volatile anesthetics: A multicenter randomized controlled study. J Cardiothorac Vasc Anesth 20:477-483, 2006

24. Xia Z, Huang Z, Ansley DM: Large-dose propofol during cardiopulmonary bypass decreases biochemical markers of myocardial injury in coronary surgery patients: A comparison with isoflurane. Anesth Analg 103:527-532, 2006

25. Jacquet L, Noirhomme P, El Khoury G, et al: Cardiac troponin I as an early marker of myocardial damage after coronary bypass surgery. Eur J Cardiothorac Surg 13:378-384, 1998

26. Lippi G, Montagnana M, Guidi GC, et al: Albumin cobalt binding and ischemia modified albumin generation: An endogenous response to ischemia? Int J Cardiol 108:410-411, 2006

27. Sinha MK, Roy D, Gaze DC, et al: Role of "Ischemia modified albumin", a new biochemical marker of myocardial ischaemia, in the early diagnosis of acute coronary syndromes.[see comment]. Emerg Med J 21:29-34, 2004

28. Abboud H, Labreuche J, Meseguer E, et al: Ischemia-modified albumin in acute stroke. Cerebrovasc Dis 23:216-220, 2007

29. Refaai MA, Wright RW, Parvin CA, et al: Ischemia-modified albumin increases after skeletal muscle ischemia during arthroscopic knee surgery. Clin Chim Acta 366:264-268, 2006
30. Turedi S, Gunduz A, Mentese A, et al: Value of ischemiamodified albumin in the diagnosis of pulmonary embolism. Am J Emergen Med 25:770-773, 2007

31. Glatz JF, van der Vusse GJ: Cellular fatty acid-binding proteins: Current concepts and future directions. Mol Cell Biochem 98:237-251, 1990

32. Kleine AH, Glatz JF, Van Nieuwenhoven FA, et al: Release of heart fatty acid-binding protein into plasma after acute myocardial infarction in man. Mol Cell Biochem 116:155-162, 1992

33. Suzuki K, Sawa Y, Kadoba K, et al: Early detection of cardiac damage with heart fatty acid-binding protein after cardiac operations. Ann Thorac Surg 65:54-58, 1998

34. Petzold T, Feindt P, Sunderdiek U, et al: Heart-type fatty acid binding protein (hFABP) in the diagnosis of myocardial damage in coronary artery bypass grafting. Eur J Cardiothorac Surg 19:859-864, 2001

35. James MK, Feldman PL, Schuster SV, et al: Opioid receptor activity of GI 87084B, a novel ultra-short acting analgesic, in isolated tissues. J Pharmacol Exp Ther 259:712-718, 1991

36. Zhao M, Joo DT, Zhao M, et al: Enhancement of spinal Nmethyl-D-aspartate receptor function by remifentanil action at deltaopioid receptors as a mechanism for acute opioid-induced hyperalgesia or tolerance. Anesthesiology 109:308-317, 2008

37. Yu CK, Li YH, Wong GT, et al: Remifentanil preconditioning confers delayed cardioprotection in the rat. Br J Anaesth 99:632-638, 2007

38. Traynor JR, Elliott J: delta-Opioid receptor subtypes and crosstalk with mu-receptors. Trends Pharmacol Sci 14:84-86, 1993

39. Salmi P, Kela J, Arvidsson U, et al: Functional interactions between delta- and mu-opioid receptors in rat thermoregulation. Eur J Pharmacol 458:101-106, 2003

40. Kato R, Foex P: Fentanyl reduces infarction but not stunning via delta-opioid receptors and protein kinase $\mathrm{C}$ in rats. $\mathrm{Br} \mathrm{J}$ Anaesth 84:608-614, 2000

41. Egan TD: Remifentanil pharmacokinetics and pharmacodynamics. A preliminary appraisal. Clin Pharmacokinet 29:80-94, 1995

42. Lowenstein E, Hallowell P, Levine FH, et al: Cardiovascular response to large doses of intravenous morphine in man. N Engl $\mathrm{J}$ Med 281:1389-1393, 1969

43. Servin FS, Billard V: Remifentanil and other opioids. Handb AQ: 2 283-311, 2008

44. Howie MB, Cheng D, Newman MF, et al: A randomized double-blinded multicenter comparison of remifentanil versus fentanyl when combined with isoflurane/propofol for early extubation in coronary artery bypass graft surgery. Anesth Analg 92:1084-1093, 2001

45. Myles P, Hunt J, Fletcher H, et al: Remifentanil, fentanyl, and cardiac surgery: A double-blinded, randomized, controlled trial of costs and outcomes. Anesthesia Analgesia 95:805-812, 2002

46. Winterhalter M, Brandl K, Rahe-Meyer N, et al: Endocrine stress response and inflammatory activation during CABG surgery. A randomized trial comparing remifentanil infusion to intermittent fentanyl. Eur J Anaesthesiol 25:326-335, 2008

47. Collard CD, Gelman S: Pathophysiology, clinical manifestations, and prevention of ischemia-reperfusion injury. Anesthesiology 94:1133-1138, 2001

48. Yellon DM, Hausenloy DJ, Yellon DM, et al: Myocardial reperfusion injury. N Engl J Med 357:1121-1135, 2007

49. Hausenloy DJ, Yellon DM, Hausenloy DJ, et al: Time to take myocardial reperfusion injury seriously. N Engl J Med 359:518-520, 2008

50. Piot C, Croisille P, Staat P, et al: Effect of cyclosporine on reperfusion injury in acute myocardial infarction. N Engl J Med 359: 473-481, 2008 


\section{AUTHOR QUERIES}

\section{AUTHOR PLEASE ANSWER ALL QUERIES}

AQ11- Graphics for all figures were supplied as poor quality. Ok as is or supply new figures.

AQ12- ED: Labels are provided in Fig. 1 but missing in legend. Please check.

AQ10 - Should there a numeral after the decimal? (If not, the decimal must be deleted.)

AQ1- Please provide highest academic degree for Shangyi Ji.

AQ3 - Please provide a city in Italy. (Is the city Caponago?)

AQ4 - Please provide city and state for Space Labs.

AQ5- Please provide city (state) and country for Roche.

AQ6 - Table 3 citation changed to Table 2. Please confirm.

AQ7- Table 4 citation changed to Table 3. Please confirm.

AQ8 - Table 5 citation changed to Table 4. Please confirm.

AQ9- References revised per journal style.

AQ2- Ref 43: Please provide volume number. 